\title{
Oralidades em tempos de possessões afroindígenas
}

\author{
Jerônimo da Silva e Silva* \\ Agenor Sarraf Pacheco**
}

\section{"De ouvido na notícia"}

No início de março de 2011, as populações de Capanema em suas localidades de Tauari e Mirasselvas, assim como as do município de Traquateua foram surpreendidas com notícias veiculadas por pessoas que viviam ou transitavam pela Vila Socorro, localizada entre os municípios de Capanema e Traquateua, no nordeste do Pará, em proximidades do km 14. Através de "boatos" e relatos de populares "curiosos", tomamos conhecimento de que nessa vila muitas crianças e adolescentes foram atormentados por espíritos, "encostos" de pessoas já falecidas. ${ }^{1}$ Após serem "atuadas" pelas entidades,

* Doutorando em Antropologia Social pela Universidade Federal do Pará (PPGA/UFPA). Líder do Grupo de Estudos Culturais na Amazônia (Geca/CNPq/UFPA) em parceria com o professor doutor Agenor Sarraf Pacheco (PPGA/PPGArtes/UFPA). Exerce assessoria e pesquisa junto ao Arquivo Público do Estado do Pará (Apep/Secult).

** Professor da Universidade Federal do Pará (UFPA), atuando nos Programas de Pós-Graduação em Artes e Antropologia. Líder do Grupo de Estudos Culturais na Amazônia (Geca/CNPq/UFPA) em parceria com o doutorando Jerônimo da Silva e Silva (PPGA/UFPA). Diretor do Arquivo Público do Estado do Pará (Apep/Secult).

1 A cidade de Capanema está localizada no nordeste paraense, na microrregião Bragantina, tem relações limítrofes com Traquateua, Maracanã, Salinópolis, Bragança, Peixe-Boi e Ourém, e fica a uma distância de $160 \mathrm{~km}$ de Belém pela rodovia BR 316 (IBGE, 1957, p. 334-335-337-339). A Lei Estadual no 5858, de 29 de setembro de 1994, elevou Traquateua à categoria de município, cuja divisão territorial é datada em 15/07/1997. A população está estimada em 27.455 habitantes segundo dados do IBGE de 2010 (cf. http://www.ibge.gov.br/cidadesat/topwindow.htm?1), agregando dezenas de vilas, ramais e povoados, caracterizados por pequenas e médias áreas agrícolas. 
tornaram-se "violentas, fortes, mudando de personalidade, invocando os mortos” (Cláudia França, entrevista realizada em 03/04/2011).

A Vila Socorro é politicamente vinculada a Traquateua. No entanto, em função de estar em situação fronteiriça com vilas, aldeias e povoações de outros municípios, esse lugar constitui-se em zona de trânsito por onde circulam pessoas de diferentes matrizes étnico-raciais, sociais, de gênero, faixa etária, credo religioso, seja para comercializar, seja para realizar visitas a parentes e amigos, adensando as formas de viver em ambientes amazônicos que podem ser interpretados como "cidades-florestas".

Os rumores populares atraíram o interesse da mídia local, de religiosos e de autoridades diversas. No dia 19 de abril de 2011, a TV Amazônia exibiu uma matéria no local das manifestações espirituais sob o título de "fatos sobrenaturais e surpreendentes na Vila Socorro”. A notícia jornalística enfatizou os "desmaios coletivos e comportamentos considerados estranhos, a fonte de medo e preocupação dos moradores", bem como a quantidade de crianças e adolescentes do sexo feminino vitimadas pelas "possessões diárias". 3

Um dos motivos desses fenômenos espirituais se deu, segundo a narrativa de alguns moradores, em função da presença dos espíritos de pessoas mortas na rodovia que liga Belém a Bragança, onde a frequência de acidentes de automóvel multiplica as cruzes na beira da estrada. Denominada popularmente como "rodovia da morte", esse local seria cenário de manifestação dos mortos, onde "saem do areal da beira da estrada" e atormentam motoristas e viajantes.

O cotidiano da vila foi profundamente alterado com a intensificação dos desmaios, convulsões e/ou "surtos" coletivos diários. As aulas na Escola Municipal Odilon Holanda Pontes precisaram ser suspensas, pois durante as atividades escolares, mais de seis desmaios/possessões foram contabilizados

2 Na compreensão de Pacheco (2006, p. 24), “cidade-floresta remete a pensar noções de uma urbanidade singular que se elabora pelos saberes, linguagens e experiências sociais de populações formadas dentro de uma outra lógica de cidade, onde antigos caminhos de roças cedem lugar à construção de ruas de chão batido, depois asfaltadas, assim como a permanência de práticas de viveres ribeirinhos nesses novos espaços de moradia”. Ainda sobre interconexões das experiências de vida do campo na cidade e vice-versa, ver: (Williams, 1989, p. 269-313).

3 Quando falamos em possessão, atuação, incorporação, demonização e outros termos alternadamente, consideramos a designação dos narradores. Quanto a possessão descontrolada, quedas, ataques, estado de inércia, sinalizam sintomas da experiência iniciática xamânica. No entanto, a identidade dos xamãs deve ser constituída na capacidade de controlar as entidades, espíritos que possuem o corpo do "escolhido" (Lewis, 1977). Omitimos o depoimento da direção, técnicos e professores neste ensaio, pois tal abordagem implicaria a construção de um texto mais denso e volumoso. 
entre os turnos da manhã e da tarde, tornando desgastante e infrutífero o desempenho escolar dos estudantes (Cláudia França, entrevista realizada em 03/04/2011).

O impacto da matéria e o desespero da população fizeram com que o jornalista em questão - Pedro Paulo ${ }^{4}$ - evocasse um apelo às pessoas que "estudam o lado espiritual", objetivando ajudar a solucionar o drama vivido pelos moradores. Sabemos da importância do discurso midiático no que tange ao direito de acesso à informação e como instituição responsável por denunciar sofrimentos vividos pela pessoa humana, no entanto, para uma análise pormenorizada da realidade em estudo, foi preciso esquadrinhar aspectos de seu cotidiano, bem como determinadas condições de vida e trabalho dos agentes históricos que ali habitam. Atentarmos para alguns elementos e práticas culturais dessas pessoas é condição sine qua non para se compreender como experiências sociais contemporâneas se articulam com tradições constituintes no fazer da história da vila e de seus moradores. ${ }^{5}$

Por se tratar de temática bastante complexa, este ensaio não pretende exaurir o entendimento desses fenômenos, nem perscrutar as diferentes motivações, interesses sociais, significações que os conformam, pois isso exigiria um tempo maior de análise e maturação de sua teia de sentidos. A preocupação inicial desta pesquisa - dada a fragilidade e o cuidado de se caminhar num ambiente de experiências tão dolorosas e espinhosas - foi estabelecer uma compreensão a partir de alguns depoimentos de moradores que experimentaram ou testemunharam aqueles acontecimentos, entrelaçando-os com discursos institucionais da Igreja e da mídia para examinar cenas do transe. No difícil exercício da escrita, procuramos reavaliar, paulatinamente, e intensificar, quando possível, o processo de análise daqueles episódios.

Nessas circunstâncias, centraremos esforços para interpretar experiências cotidianas, interagindo com narrativas de servidores públicos, religiosos, jornalistas e estudantes. De antemão, pelas observações realizadas, esses narradores colocam em questionamento o discurso do "sobrenatural" estruturado na fala de terceiros, questionam olhares institucionais, percebendo essas

4 Funcionário da TV Amazônia, atualmente exerce a função de repórter investigativo, voltado para temas associados à violência ou acontecimentos de forte apelo emocional. Agradecemos a esse repórter pelas informações fornecidas.

5 Falamos em "experiência" inspirados no entendimento de Edward. P. Thompson (1981, p. 182), onde sujeitos históricos "experimentam suas situações e relações produtivas determinadas como necessidades e interesses e antagonismos, e em seguida 'tratam' essa experiência em sua consciência e sua cultura”. 
práticas culturais enquanto formas contínuas de estruturar e dar sentido para suas tradições (Hall, 1999, p. 10-13).

As vozes do lugar, por serem tributárias de matrizes culturais indígenas e africanas, sem negar a presença de colonizadores europeus filhos de um cristianismo primitivo ${ }^{6}$ e do catolicismo devocional, os quais foram ressignificados e adensaram a construção compartilhada de cosmologias de povos de tradições orais em Capanema, Traquateua, Maracanã, Salinópolis, Bragança, Peixe-Boi e Ourém, desmontam interpretações apressadas formuladas especialmente pelos meios de comunicação, olvidando experiências de agentes históricos conformados no seio de culturas afroindígenas nesse portal da Amazônia brasileira.

O conjunto das experiências de possessões que estremeceram o cotidiano aparentemente tranquilo daqueles lugares da Amazônia Bragantina ${ }^{7}$ completa-se com a chegada na Vila Socorro de Cristiano - um jovem dotado de especiais propriedades xamânicas, pronto para combater os espíritos, entre o céu e a terra, capaz de não apenas "exorcizar" essas manifestações espirituais, mas catalisar esperanças daqueles moradores da floresta amazônica. ${ }^{8}$ Nos rituais de incorporação que não esperaram o cair da noite, práticas mágico-terapêuticas desempenhadas pelo xamã visaram acalmar espíritos ou encantados que tomaram corpos de crianças e adolescentes do sexo feminino.

Desse modo, as possessões ocorridas, a partir da ótica do rezador Cristiano e de alguns populares, podem ser identificadas em três direções: entidades incorpóreas, mortos-vivos e demônios. A primeira aponta pistas de dons que algumas das meninas sobressaltadas por possessões trouxeram como sinas $^{9}$ de suas trajetórias humanas e espirituais para assumirem-se como novos xamãs da região. A segunda indica espíritos peregrinos de antigos habitantes

6 O uso do termo "primitivo" refere-se à matriz de um cristianismo oral disseminado em peregrinações, pregações e ensinamentos por Jesus Cristo em terras do Oriente Médio.

7 Cunhamos a expressão "Amazônia Bragantina" para enfatizar hábitos alimentares, linguagens, religiosidades, costumes e dinâmica de populaçôes que transitam em vilas, sítios, comunidades, "terrenos", encruzilhadas e "beira de estrada" nas fronteiras campo/cidade de área do nordeste paraense, revelando experiências que, sem negar diferenças desses territórios, quebram noções de isolamento administrativo entre os municípios para traduzir específicos modos de viver na plural Amazônia.

8 Utilizamos livremente termos, expressões e designações espirituais xamânicas ao papel de Cristiano na comunidade. Lembramos que o depoimento dos entrevistados é igualmente variável na definição identitária cultural desse jovem.

9 No contexto amazônico mencionamos o conceito de "sina", "destino" ou "fado" tal como pensado por Fares (2008) no seu estudo sobre a diversidade de matintapereiras na região Bragantina. 
da região que, por motivos diversos, continuam vagando e procurando contatos com o povoado. E a terceira são espíritos malignos, que guerreiam com forças do bem naquele território.

Esse universo de encantados, espíritos e demônios permite notar que práticas culturais comungadas no passado e no presente pelas populações rurais e urbanas da Amazônia Bragantina não constituem uma genealogia pura ou acontecimento fundante, mas forjaram-se sob códigos compósitos e fluidos, sofrendo transformações do local onde são operadas (Bhabha, 2003; Hall, 2009). ${ }^{10}$

As vivências dos agentes históricos são registradas à luz da metodologia da história oral, valorizando-se formas da linguagem corporal, silêncios, gestos e intensidade das narrativas (Zumthor, 2000). Os múltiplos papéis que os moradores assumem na afirmação e dinâmica das identidades e as cosmovisões construídas nas representações do mundo natural, plasmado na religiosidade amazônica, são pensados na articulação dos intelectuais dos estudos culturais e pós-coloniais, alcançando formulações da antropologia das religiões.

\section{"Vila(s) em transe"}

Entre os meses de abril e junho de 2011, estivemos realizando visitas na Vila Socorro com objetivo de acompanhar os "fenômenos sobrenaturais" e escutar a narrativa dos moradores. No ato de ouvir os estudantes da vila, fomos surpreendidos pela postura calma e serena de que os fatos ocorridos e tratados com ineditismo pelos meios de comunicação nos municípios vizinhos eram, na verdade, algo comum, pois "não era[m] de hoje, e sim de muito antigamente".

Ouvi falar disso, de ver, era quando tava cursando o ensino médio. Saímos da sala na hora do intervalo e fomos para a praça, depois vimos um tumulto, quando chegamos lá estava uma menina da $7^{\text {a }}$ série e a prima dela, que chegou perto, ele passou pra ela também [...] elas estava possessa, né? Daí foi aquele medo, ninguém ficava lá. Mas depois outras pessoas foram "caindo", não sei se virou moda [risos], mas daí dava na comunidade do Cajueiro, Vila Fátima, Alves de Moura, Estirão e Anoerá dos Gamas. No onibus mesmo, na volta da escola era todo dia, a gente que segurava eles

10 Expressão utilizada por vários narradores ao mencionarem a atividade de Cristiano. 
pra não se machucarem. Mas sempre começa na escola, depois passa pra rua. Mas a gente vê que é coisa do outro mundo, elas ficam com a feição completamente mudada é como se tivesse com muito ódio [...] é outra pessoa. Teve um caso no balneário, as pessoas pulavam da ponte, quando essa pulou, começou a se entortar todinha, eu estava lá. Aí ela caiu na água e o pessoal perceberam e tiraram ela de lá. Se a gente for falar mesmo, sempre foi assim. (Joseane de Oliveira, entrevista realizada em 17/04/2011).

O depoimento oral permite alcançar experiências compartilhadas por pessoas que, na maioria dos casos, apenas estudavam na Vila Socorro, tendo residência em outras localidades. $O$ transporte escolar não era apenas o palco das manifestações desconhecidas, mas o momento onde os jovens, sozinhos, longe da tutoria de pais e professores, criavam estratégias para afirmar papéis identitários, hierarquias e redes de solidariedade entre os ramais que interligam as vilas.

O depoimento dessa jovem conecta dois elementos que surgem como aspectos aparentemente contraditórios de uma mesma estrutura de sentimentos que atravessa culturas indígenas e negras em solo da Amazônia Bragantina (Williams, 1979): tanto o medo como a aceitação de uma tradição de possessões são narrados de modo indissociado, ou seja, se por um lado, o medo é um sinal de negação, fuga ou mesmo uma forma de demonização ou estranhamento causada pela intolerância religiosa do catolicismo ortodoxo na história da Amazônia, por outro, a aceitação e/ou naturalização das possessões podem ser entendidas como patrimônio imaterial de um ethos ritualístico, baseado na ancestralidade e na composição imemorial de sabedorias orais de heranças afroindígenas, que, diante do olhar exógeno (mídia, curiosos, transeuntes diversos) reveste-se de negação. ${ }^{11}$

As possessões atingiam meninas entre 10 e 16 anos, inicialmente no horário escolar e depois no espaço doméstico e público. A narradora ressalta a multiplicidade desses eventos nas circunvizinhanças, enfatizando a escola como espaço público que agrega a maioria das crianças e adolescentes dispersos em dezenas de povoados e vilas no interior do município de Traquateua.

11 A ambiguidade apresentada acima é um componente específico da escrita racional acadêmica. As pessoas entrevistadas denotam leveza invejável no trato dessas compreensões. Pensamos a relação entre "medo" e "aceitação" amparados no conceito de "estrutura de sentimentos", onde identidades culturais criam lógicas específicas ao plasmar sentimentos/sensibilidades, rejeitadas como contraditórias no discurso logocêntrico (Williams, 1979, p. 130-137). 
Todavia, o imaginário desses sujeitos sociais não se curva ao argumento do inexplicável. Homens e mulheres da floresta têm referências explicativas e abundantes, inscritas no acervo de suas tradições orais, sabedorias populares e relação com a natureza (Antonacci, 2001, p. 105-138). Significativo é o relato da estudante Glória Maria:

Tem o caso de um rapaz também que quando incorporava virava o "Mão de Gancho". Que era lenda de um homem que foi morto e teve os pés e a mão cortados, lá no rio Quatipuru. E como não acharam o corpo dele [...] ele sempre aparece com a mão de um gancho mesmo, aí ele possui e castiga os outros. Porque nessa época ainda não tinha ponte e eles [pais, avós] diziam que a ponte do rio era de madeira e a água era muito escura com galhos e muita gente morreu lá, é o "Mão de Gancho" que leva, leva pra perto da ponte, onde tem uma pedra, e é lá que ele vive, e o pior que debaixo dessa pedra é fundo mesmo. [...] esse rapaz quando era possuído pelo "Mão de Gancho" andava de cabeça pra baixo, tipo plantando bananeira, o cabelo ficava "armado" e subia nas paredes, dava muito medo. Os pastores da Assembleia [de Deus], da Quadrangular e os padres nem encostaram nele [risos]. Esses casos era só com o Cristiano. Na época dos meus pais, tinha uma escola aqui que aparecia o "menino da caixa", todos os antigos contam isso: "Um dia, na hora do recreio apareceu em cima da caixa d'água da escola um menino de 7 anos, bem pretinho, dançando, era de dia e todo mundo viu! O professor subiu lá e não tinha ninguém [...] nessa hora caíram bem uns seis no chão se debatendo, todo mundo teve febre e dor de cabeça. Diz que era gente carregada em carroça pro posto [de Saúde], parece ser uma coisa daqui mesmo. (Glória Maria, entrevista realizada em 17/04/2011).

Estamos diante de memórias que recuperam em tradições orais entidades negras e europeias, acionando poderes sobrenaturais de pelo menos duas ou três gerações. A história local contada pelos mais experientes é reintegrada e atualizada em versões da narrativa de Glória Maria. Os enredos são entrelaçados à memória social da cultura local e criam sentidos para vivências do presente. A comunidade refaz a identidade memorial pretérita, e, simultaneamente, questiona a fragilidade da ação das igrejas locais e seus "cristianismos".

A resistência desses sujeitos em relação ao modelo explicativo cristão encontra ressonância justificada na crença de que possessões e transes são explicados ora pela presença da força mágica dos rios e da ação do "Mão de Gancho" e sua morada subaquática, na paisagem encantada da floresta, ora 
como uma herança espiritual transmitida por várias gerações. Sintomaticamente, o espaço escolar é mencionado como um ambiente propício para a manifestação do espírito dos mortos e entidades diversas no imaginário ancestral dos moradores, onde netos, filhos, pais e avós testemunhavam casos semelhantes na história familiar (Le Goff, 2003, p. 207-209).

Um relato que diversifica a tese dos contínuos transes espirituais na população das vilas e com longa duração histórica é o depoimento de dona Nazaré, para quem "essas presepadas são devido o afastamento de Deus e da Igreja dos jovens, aí depois que o mal pega é que resolve voltar pra Igreja, mas antigamente que o povo obedecia os mandamentos isso quase não tinha" (Nazaré Mendonça Alves, entrevista realizada em 12/05/2011).

Evocamos o surpreendente depoimento de Jair Nunes, colono de 63 anos, residente no ramal que liga Vila Socorro à localidade de Tentuga, onde vive com a esposa e seus cinco filhos. $\mathrm{O}$ entrevistado interpreta essas manifestações no seio da família como herança espiritual oriunda do panteão das encantarias indígenas.

Aqui na minha casa tem muito disso, essa aqui é uma que de vez quando "cai". Ela já caiu na escola umas duas vezes [Rafaela - filha de 9 anos], mas é assim [...] é tipo uma coisa que vem da minha avó, sabe? Eu me lembro que o meu tio Antônio subia era em pé de coqueiro de manhã e só saía na boca da noite, passava o dia todo encantado lá em riba, era um negócio feio, nisso eu tinha 11 anos. Olhe, eu não padeço disso não, mas minha irmã teve que fazer conta [benzedeira] pra não ser levada por eles [encantados]. Isso de ficar agarrado em pé de pau, enfezado, aparece até em outras casas aí na frente. Essa aí [Rafaela] fica valente mas é só na época [...] Ninguém não fala disso em casa não, a gente às vezes escuta as mulher falando que isso é dos índios que viviam aqui da banda dos Cacicó, mas não acredito não, tem umas fala que é só invenção. (Jair Nunes, entrevista realizada em $28 / 04 / 2011){ }^{12}$

12 Nas famílias locais há relatos que mencionam que essa região do nordeste paraense foi habitada por uma aldeia indígena chamada de tribo dos Cacicó, e que as encantarias que povoam a floresta ou o espírito desses índios habitam a região. Essas informações não representam unanimidade, pelo contrário, a maior parte das pessoas questionadas a esse respeito ou não têm conhecimento, ou negam veementemente tais suposições. Por enquanto, não temos informação documental, etnográfica ou arqueológica que fundamente essas constatações, o que, evidentemente, não anula a forte herança cultural afroindígena disseminada em cantos e recantos do mundo amazônico. Para maiores informaçôes, entre outros, acompanhar leituras de Gomes (2005) e Pacheco (2009). 
O tempo das encantarias descritas por Jair emerge entrelaçado à memória familiar. Trata-se de entidades que ao se manifestarem em interações com o mundo vegetal - árvores, matas, raízes, folhas - ameaçam as pessoas atingidas, levando-as para reinos e regióes subaquáticas. Esses seres, na perspectiva de Jair, marcam a história das famílias locais, interligando as representações identitárias com os núcleos que familiares elaboram de si. Nesses lugares, ainda que ações incorporativas sejam corriqueiras, o silêncio parece ser poderoso signo de comunicação cultural, pois a narrativa é exercida longe das crianças, no "pé de orelha" e "cochichos" no fundo do quintal. A performance na oralidade dos moradores contrastava com as técnicas investigativas dos jornalistas locais: a postura teatral exigida diante de câmeras e gravadores, a relação objetiva, quase mecânica de perguntas e respostas e a exigência de reduzir seus modos de vida a definições sintéticas são características do discurso midiático. Com isso, não apreendem olhares, gestos, risos, expressões faciais, tosses e outras formas de compartilhar experiências sociais. ${ }^{13}$

A incapacidade da Igreja Evangélica e da Igreja Católica é enunciada sem surpresa e com desdém por Joseane e Glória Maria, que justificam a inoperância das lideranças religiosas sob a constatação de que são "pessoas que não têm fé suficiente", ou de que "esse tipo de coisa é pra quem tem uma vida muito próxima de Deus", questionando a autoridade de lideranças institucionais cristãs. Um reforço da fala desses sujeitos é intensificado quando um representante da Igreja Católica realiza um "exorcismo" mal sucedido no interior da Igreja, no final do mês de abril, provocando grande alvoroço na Vila Socorro.

Acho que foi na semana passada, quando o diácono daqui botou todos os que caíam dentro da igreja. Nisso, todo mundo foi embora, só ficou ele lá dentro, trancado com umas 12 ou 13 meninas. Passou-se uma meia hora e só ouvimos a voz dele brigando, dizendo: "Sai daqui demônio, deixa essas inocente em paz, Satanás." Hum! Foi só ele fechar a boca [...] daqui a pouco ouvimos foi os gritos dele e delas - pense num negócio feio - a coordenadora da escola entrou na igreja e o alvoroço tava armado [...] tinha umas

13 Pensamos o conceito de encantaria como um conjunto de praticas mágico-religiosas que revela ritos e transformações sob o signo geral da religião brasileira dos encantados (Prandi, 2004, p. 7-9). Maués (1995, p. 189-201) que compreende os encantados da mata como oiaras, caruanas, que se manifestam no trabalho dos pajés denominados de "guias" ou "cavalheiros". 
duas que estavam era no soco com ele, chega escorria sangue na blusa e haja gente pra segurar, se não fosse a coordenadora elas iam matar ele [...] quando a igreja foi aberta elas saíram correndo pelos ramal, tinha uma que mergulhava nas maliça ${ }^{14}$ de peito assim, parecia que deslizava em sabão, no meio de pedra, tronco de pau e tudo. Nesse dia parecia que tava todo mundo doido. Diz que o diácono levou uns quatro pontos na boca e os espíritos só foram sair pra perto de meia-noite. (Joseane de Oliveira, entrevista realizada em 17/04/2011).

A fala repreensiva e demonizadora do sacerdote despertou um acesso de fúria inimaginável na postura das crianças e jovens no interior do templo. A violência e a fuga descontrolada fazem entrever táticas de recusa radical, negação explícita das formas de nomeação, controle e intolerância do catolicismo romanizador.

Nas incursões iniciais, esboçamos uma tentativa de compreender que agentes históricos envolvidos em situações de conflito constituem, com base nessas experiências, papéis sociais, principalmente ao articularem sentidos criados tanto por pessoas de localidades limítrofes como de representantes de poderes instituídos e meios de comunicação. A interpretação da furiosa reação espiritual dentro da igreja narrada por Joseane - depoente evangélica - acena estratégias de afirmação de sua religião e negação do catolicismo nos jogos da memória. Nessa assertiva, podemos operar com a tese de que a "memória é um processo individual, que ocorre no meio social dinâmico, valendo-se de instrumentos socialmente criados e compartilhados. Em vista disso, as recordaçóes podem ser semelhantes, contraditórias ou sobrepostas" (Portelli, 1997, p. 16).

Não adotamos a postura ingênua da pergunta como indicativo do encontro com uma verdade "em-si", mas buscamos significações culturais nos elementos expressos em compreensões dos narradores, ou ainda, não buscamos um sentido lógico, mas tentamos captar quais práticas culturais permitem urdir uma lógica diversa, para a qual o saber ocidental é tão estranho (Viveiros de Castro, 1996). ${ }^{15}$

14 Arbusto dotado de espinhos, conhecido no Nordeste como "malicia".

15 Pensamos no ato de narrar como uma forma de apontar "feixes" dinâmicos que perpassam a linguagem da cultura (Burke, 1992, p. 327-348), dando ao narrador a oportunidade de "expressar e lidar com suas lembranças dolorosas a até mesmo dar um novo sentido às velhas histórias” (Thomson, 1997, p. 63). 
As questões apresentadas acima são enriquecidas com a chegada de Cristiano na Vila Socorro. As vivências particulares desse jovem rezador, dotado de propriedades xamânicas, e revestido de reconhecida autoridade social e espiritual, permitiram apreender resistência e mesclas culturais da ancestralidade de cosmologias afroindígenas. Igualmente a interpretação de suas experiências faz visibilizar uma das surpreendentes formas de como populações amazônicas de tradições orais recepcionaram e ressignificaram orientações do cristianismo primitivo, catolicismo devocional e ultramontano entre os séculos XVII e XIX, sem esquecer suas ressonâncias em tempos presentes.

\section{A peleja: "com o Índio Flechador ninguém pode"}

Durante a pesquisa de campo, conversamos com profissionais da saúde e da educação na vila e fomos aconselhados a procurar autorização de representantes do poder municipal. Tivemos oportunidade de conversar com Wilson, secretário municipal de Ciência e Tecnologia em Traquateua. Fomos acolhidos em sua residência com toda cortesia, mesmo que o entrevistado estivesse reunido com amigos num típico almoço de sábado.

Formado em ciências da computação, Wilson demonstrou em sua fala uma tentativa de aproximar o que chamou de "coisas sobrenaturais" das explicações científicas pensadas na academia - motivações psicológicas, sociológicas ou econômicas. O secretário ressaltou o esforço da Prefeitura Municipal de Traquateua em relação a esses fatos e a formação de uma comissão composta por familiares e autoridades públicas, com objetivo de atender as pessoas acometidas por "possessão demoníaca".

Há duas semanas o professor Joel - diretor da Escola Odilon - fez reunião e tirou comissão para analisar os fatos que estavam ocorrendo. Doze garotas estavam acometidas pelo problema. No seu parecer todas estavam com problemas espirituais. A comissão era composta pela direção da escola, funcionários da saúde e educação, entidades religiosas e representantes dos pais dos alunos. Na verdade, essas jovens estudam na Vila Socorro, mas são das comunidades ao redor. Nessa comissão foi detectada a necessidade de visitar as famílias e conversar com as vítimas [...] e chegamos à conclusão que duas ou três estão realmente com problema espiritual, acometidas por possessão demoníaca, as demais estão com problemas psicológicos, são 
envolvidas pelas outras que estão e passam, por sua vez, a ter afinidades com as vítimas, se sensibilizando com os problemas das outras, criando vínculos com as possuídas. $\mathrm{O}$ diácono da vila acha que é problema psicológico, mas assim, ele também acredita que tem duas ou três que também são possuídas. [...] nós fomos visitar no $\mathrm{km} 15$ uma das garotas [Jéssica] que é a que tá com problema maior, ela chegou a surrar dez homens. (Wilson, entrevista realizada em 06/05/2011). ${ }^{16}$

O estilo de narrar de Wilson expressa a ambiguidade de uma identidade que busca conciliar a lógica racional com a dinâmica das tradições religiosas. Para ele a possessão existe, mas nem todas as crianças que desmaiam têm convulsões e ímpetos de violência, as manifestações espirituais ocorrem em sujeitos e tempos específicos. O fato de existirem laços de amizade entre as crianças, de dividirem espaços, angústias e perpetuarem vínculos de solidariedade faz com que, emocionalmente, comunguem com a vitimização de seus iguais. Por conseguinte, o discurso demonizador ainda prevalece como um fundamento inquestionável - pano de fundo - energia motriz, que aciona o medo na comunidade e explica a natureza das possessões. ${ }^{17}$

A demonização através do medo tem apenas força de nomeação, ou seja, quando esses sujeitos mencionam Lúcifer, Diabo e Demônio, os substituem fartamente por espíritos, desencarnados ou mortos. Isso nos faz pensar que, ao designarem essas entidades nesses termos, estão apenas ressaltando o aspecto negativo das experiências testemunhadas por populações formadas em outros circuitos de crenças e relações com a natureza (Delumeau, 1989, p. 84-96; Muchembled, 2001, p. 17-49; Souza, 1993, p. 177). Vejamos como o narrador sobrepõe essas interpretações:

[...] Nessas vilas isso é de muito tempo [...] lá naquela região é acometida por bastantes situações trágicas, acidentes, violência, tem um cidadão aqui que o pai dele chegou a matar com 14 facadas - ele é pernambucano e o pai é cearense - um cidadão chamado de Chiquinho, que é o espírito principal que aterroriza toda a população, e ele disse que só vai ser liberto quando

16 A garota em questão tem 12 anos e vamos chamá-la de Jéssica, pois teremos oportunidade de conversar com ela na visitação escolar registrada a seguir.

17 Interessante lembrarmos o drama vivido pelo moleiro mediterrâneo diante da inquisição e do embate entre lógicas culturais sobrepostas, registrado magnificamente na caligrafia de $O$ queijo e os vermes (Ginzburg, 2006). 
desenterrarem uma faca que tá enterrada lá perto da Vila Socorro [...] é o espírito que mais incorpora lá. Já fizeram vários grupos de busca para achar essa bendita faca, mas não acham nada, parece uma coisa. Ali, facadas, "terçadadas" e acidente de briga de família são muito comuns. (Wilson, entrevista realizada em 06/05/2011).

Temos um imaginário que reforça a memória de pessoas que faleceram em circunstâncias trágicas, inesperadas ou violentas. Nessas narrativas, os espíritos das pessoas mortas exigem a realização de um pedido para que a comunidade volte a viver em paz. Existe uma "missão", uma dívida das pessoas vivas para com essas entidades em sua errância, na tentativa dos moradores de desencravarem o facão do tronco submerso do Igarapé, ou ainda, de pessoas vítimas de trânsito que mandam mensagens aos familiares. ${ }^{18}$

Ao mesmo tempo em que os narradores interpretam esses acontecimentos como uma manifestação demoníaca, uma maldição que caracteriza quem vive na região, também vivenciam essas experiências como uma vocação dada por Deus para libertar os espíritos que "estão presos nesse mundo", conforme assinalou Wilson. No decorrer da análise das narrativas coletadas vemos emergir, na articulação de sabedorias orais, uma adequação as súbitas incorporações das crianças e jovens com a elaboração de uma identidade social capaz de fazer confluir ramais, vilas e povoados em crenças e histórias cuja simbiose tanto reedita velhos preconceitos contra formas de manifestações espirituais populares quanto renova tradições de religiões não canônicas praticadas por populações amazônicas.

Elas estavam com problemas na escola e em casa, e no dia 28 de abril, o diácono Antônio Moura, auxiliar do padre Maurício, pároco de Traquateua, fez uma reunião com as 12 jovens na Igreja, e nesse dia elas tiveram uma manifestação sobrenatural muito forte. Quebraram imagens, carteiras nas costas do diácono, e ele foi obrigado a usar da força física para não ser mutilado. Também levei um jovem tido como rezador e exorcista, que é o Cristiano, na região entre Castanhal e Vizeu ele é o único exorcista que a

18 Estamos conectados às compreensões de Eliade a respeito do imaginário aquático: "Tanto no plano cosmológico como no plano antropológico, a imersão nas águas não é uma extinção definitiva, mas a reintegração passageira do indistinto, seguida de uma nova criação, de uma nova vida ou de um novo homem, segundo se trate de um momento cósmico, biológico ou soteriológico" (Eliade, 1991, p. 152; Figueiredo, 2008; Galvão, 1975). 
gente tem conhecimento que resolve as situações, reza em criança, adulto e não cobra nada, todo mundo aqui já viu o que ele fez. (Wilson, entrevista realizada em 06/05/2011).

Desde as primeiras investidas no local de pesquisa, ouvimos falar do rezador exorcista Cristiano e de sua capacidade de sempre "resolver os problemas de espírito em toda essa região”. No início de maio, conseguimos autorização para acompanhar a comitiva responsável pelo "apaziguamento espiritual” na escola e nas vilas. Caminhamos ao local e, quando iniciávamos uma entrevista com o jovem rezador, fomos comunicados pela direção que a adolescente Jéssica estava passando mal na sala da direção. O calor e o tumulto na Escola Odilon Holanda era insuportavelmente reforçado por dezenas de alunos e curiosos que se espremiam no interior do recinto para ver de perto o acontecimento.

$\mathrm{Na}$ sala da direção, estava o diretor, a coordenadora e uma responsável por Jéssica, a qual se encontrava no centro da sala, sentada com a cabeça baixa e as mãos para trás. Cristiano, um jovem de 23 anos, magro, com aproximadamente 1,75 de altura e fortes traços afroindígenas, ao entrar na escola baixou a cabeça e começou a falar em tom de sussurro, com expressão facial tensa. Ao se aproximar de Jéssica, pediu que a deixassem relaxada e não fizessem barulho. Ouçamos passagens dessa "cura espiritual":

Hum [...] olha, isso que tá acontecendo contigo, tu pensa que é bom, mas não é não! Eles tão assim [...] mas depois vão te pedir coisa ruim pra ti fazer. Eu sei que tu pergunta como eu sei disso, né? Mas eu sei porque era assim também, esse que tá aí contigo não [é] do bem não. Mas agora ele vai aparecer e vai embora porque eu vou mandar embora em nome de Jesus! Eu disse EM NOME DE JESUS, TÁ OUVINDO SATANÁS?! Agora, tu diz que bate em todo mundo, pois eu te desafio a bater em mim - BATE, PODE BATER! EU TÔ MANDANDO! Tu não bate em mim porque eu estou com sete anjos com espada de fogo aqui e com o Caboclo Flechador [risos], e com esse ninguém pode! [...] Agora pega a Bíblia aqui, pega póe no peito e reza comigo o Pai Nosso, depois dessa reza tu vai ficar boa, mas depois, se tu ficar triste de novo ele volta, então [...] a senhora é a tia? Parente? Pois é, leve ela na missa todo dia até ela dormir direito, enquanto ela tiver vendo vulto nas paredes e não dormir bem, continue tudo. Ponha uma Bíblia debaixo da cabeça de noite [...] é só isso. (Cristiano, depoimento colhido em 12/05/2011). 
Cristiano não estabeleceu contato físico com Jéssica, manteve-se sentado de frente para ela com olhar altivo e com tom de voz elevado, a garota não manifestou movimentos bruscos, entretanto, olhava firmemente todos na sala, suas expressões faciais oscilavam entre um leve riso cínico, choro compulsivo e vermelhidão nos olhos na iminência de ato violento. A jovem, não respondia às investidas do rezador, limitava-se a acenar com a cabeça, apenas a voz de Cristiano ecoava no ambiente escolar. O rezador menciona a presença de seres espirituais, olhando para os lados, como se não estivesse em uma sala com pessoas, mas sim conversando com as entidades.

Aspecto importante é a preocupação com a vida espiritual de Jéssica, após o afastamento do espírito. Sua orientação insiste no acompanhamento familiar, na boa alimentação e na ida à Igreja. O Caboclo Flechador é apresentado como um guia espiritual fortíssimo capaz de transitar com auxílio dos sete anjos que fazem a sua guarda. Essa entidade, veremos, aparece entrelaçada ao poder de Jesus Cristo. A ida à Igreja é uma forma de manter a "cura espiritual"; o poder da libertação, no entanto, é reivindicado junto aos encantados, denotando, dessa forma, níveis de autoridades espirituais. ${ }^{19}$

Enquanto Cristiano conversava com a responsável de Jéssica na escola, muitas pessoas chegaram desesperadas afirmando que "eles [os espíritos] estavam se atuando dentro das casas”. A partir desse instante, acompanhamos o jovem rezador num percurso a três locais diferentes: duas crianças de 8 e 9 anos foram rezadas dentro do ônibus escolar, onde ameaçavam entrar no [corpo] do motorista para "virar o ônibus"; uma adolescente de 14 anos se debatia na calçada ao lado da Igreja, e, amparada pelas colegas, dizia estar sendo possuída pelo falecido Chiquinho; e, posteriormente, outra adolescente de 14 anos "incorporou" dentro de sua residência, exigindo um longo período de reza e "pendenga" entre a entidade e o rezador. Observemos alguns aspectos do discurso do xamã neste último caso: ${ }^{20}$

19 Em uma definição parcial, o Caboclo Flechador é uma entidade com linha específica nas encantarias da pajelança rural (Maués, 1995), que vive no reino da mata nas raízes do "Tabocal - Bambu Amarelo, grande touceira de bambu, morada do Caboclo Fleixeiro Gentil de Arruda [...] e outras categorias de caboclos, como 'Seu' Boiadeiro, Zé Baiano, Chapéu de Couro, Corre-Campo, e 'Mestre' Gêrerê" (Figueiredo, 1979, p. 71), acrescentamos a estes o Caboclo D’Água, registrado no clássico de Cascudo (1954, p. 325-327).

20 Interpretamos "pendenga" como sinônimo de luta, combate e rixa, na forma como são evocados por Cristiano. 
Por que tu não olha pra mim, por quê? Viu coisa mais forte? Tá mais pesado do meu lado? Como é o teu nome? De onde tu vem? Por que tu deixa tuas colegas se aproximar de ti e eu não? [...] vamos conversar nós dois, tu vai me agredir e eu vou te consolar. Olha dentro do meu olho - tem medo? Tu quer ficar boa... Não? Todo mundo quer ter vida normal [...] eu quero lutar pela vida! Me diz, quem é tu que perturba essa jovem? Assim a gente pode te ajudar, o que é? Tá com dor de cabeça? [...] tá com vontade de voar em mim pra me dá-lhe, né? Vem! Se aproxima de mim! - não, não, pode soltar ela, tá amarrada pelo guia - vem, eu quero ver se tu pode, VEM SATANÁS! BATE! EU QUERO QUE TU BATA NO ROSTO AQUI! BEM AQUI! [o rezador bate no peito e no próprio rosto em tom autoritário] tu quer me esganar, me azunhar [arranhar], né? Mas o Senhor é meu pastor, o braço dele é meu escudo! Eu tô aqui no teu nome, Senhor Deus: vem um pastor que é preparado e tu quer dá-lhe, vem um diácono servo de Deus, tu vem e dá-lhe e eu [...] um simples pecador, um homem qualquer, por que o inimigo não quer me dá-lhe? O quê? Tu vai matar ela? [risos] vai nada! [...] espera [...] olha a janela! Pulou, fugiu [...] Calma, não deixa ela se bater não, a onda dele [inimigo] é machucar o corpo dela. (Cristiano, depoimento colhido em 12/05/2011).

O rezador discursou para a comunidade e, ao mesmo tempo, se dirigiu à Madalena. ${ }^{21}$ Notamos que diversas vezes as pessoas estavam atentas mais à mensagem do exorcista do que ao ritual de libertação em si. A comunidade endossou a autoridade espiritual, de modo que ele circulou livremente pelas casas sem qualquer formalidade, constrangimento ou cerimônia. $\mathrm{O}$ desafio público à entidade que possuiu o corpo, a coragem e a proximidade com que enfrentou o "encosto" impressionou crentes e curiosos. Madalena estava na sala, sentada no sofá enquanto sua mãe lia algumas passagens bíblicas. $\mathrm{O}$ rezador se aproximou bastante e desafiou o espírito a espancá-lo, a adolescente ficou de pé com as mãos para trás, como se estivessem atadas, e apenas emitia grunhidos com o rosto quase que colado na face do guia espiritual.

A autoridade do narrador é afirmada em oposição aos líderes das religiões institucionais na vila. Pastores evangélicos e diáconos católicos, mesmo

21 Madalena é um nome fictício. A ética e o bom senso na metodologia da história oral exigem que preservemos a identidade de sujeitos sociais e relatos que não tivemos autorização e acesso na pesquisa de campo (Maués, 2008; Portelli, 1997, p. 22). 
sendo "homens santos e abençoados", não tinham o poder de Deus para libertar os enfermos espirituais que ali se apresentavam.

O exorcismo é interrompido quando Madalena fica de pé no sofá, esgueira-se pelas paredes e salta de costas para a janela, e desta para o quintal ao lado e adentra no matagal. A forma rápida e súbita do movimento corpóreo da adolescente, além de ser vista como um sinal de possessão é interpretado pelas testemunhas como poder do rezador. A esse respeito revelou dona Antônia Almeida: "O inimigo foge quando vê a presença de Deus."

Durante quase três horas, acompanhamos Cristiano transitando de um lado para o outro da vila. Nesse território, enquanto uma dezena de pessoas o seguia, outros o observavam com um terço no pescoço sentado na frente de suas casas. Impossível não retermos na memória alguns aspectos dessa estética visual de um cotidiano em ebulição.

Primeiro, a forma como as crianças acompanhavam tudo, sem restrição alguma a respeito das vítimas (assuntos sobre problemas familiares, postura sexual, opinião de pais, vizinhos), vivenciando a experiência de êxtase umas das outras. Segundo, a maneira como a comunidade estava magnetizada pelo medo e fascinada pelo aparente excêntrico evento. Nesse palco, algumas mulheres e crianças choravam continuamente, havia um clima de instabilidade emocional intenso. E terceiro, o cenário turbulento se contrapõe à calma do entrevistado. De andar lento e cadenciado, circulava na vila inteira com a cabeça erguida, pronunciando palavras inaudíveis e sempre com a mão direita passando-a na cabeça e no queixo, algo constante e involuntário.

De hábitos simples, após o término das rezas, Cristiano sentou na calçada e pediu um copo de água para uma senhora, que lhe ofereceu pão e suco. Enquanto se alimentava aproveitamos para nos aproximar e acabamos por ouvir como as encantarias emergem em profusão com os componentes do cristianismo não ortodoxo, em que uma das matrizes é afroindígena:

Tá vendo professor? Tá vendo o inimigo? Vou te dizer uma coisa, vou te dizer uma verdade: Deus sabe o que faz e o povo não sabe o que fala. Eu já passei por isso, mas não assim, mas d’outro jeito [...] isso é uma coisa que não tem explicação, se eu disser o que é que estou vendo, vão dizer que tô em outro mundo. Aqui, duas são espírito mesmo, mas as outras são "encosto", parece quando uma pessoa pega um choque na tomada e passa pras outra que pega nesse pessoa, né? É mais um negócio da cabeça dela mesmo, isso tem que falar com a família [...] olhe o guia que me segue é 
o Caboclo Flechador, tem outros, mas ele é que comanda os anjos tudo. Eu passava era de dia no meio das brenhas, surrado por ele, só depois que aprendi é que fui rezar e expulsar as força do inimigo, esse meu guia é o mais poderoso, com ele ninguém pode. $\mathrm{O}$ senhor viu aquela menina querendo me bater? Ela tava amarrada pelos anjos e pelas cordas do guia [...] Deus me deu isso foi pra fazer o bem. (Cristiano, depoimento colhido em 12/05/2011).

A oposição entre bem e mal, o papel dos anjos como guardiões, protetores e mensageiros espirituais e a evocação de Deus como o nome que tem autoridade suprema sobre os demônios e espíritos são referências culturais de um cristianismo primitivo migrante e em reatualização que, nas palavras do narrador é reforçado pela ação do Caboclo Flechador, pai da corrente dos encantados com a qual Cristiano trabalha.

As representações religiosas do rezador são entrelaçadas a uma forte sensibilidade frente ao sofrimento das crianças em questão. $\mathrm{O}$ ato de compartilhar as experiências dolorosas no corpo e na voz, bem como a percepção de que a maioria daqueles agentes cujos corpos tornam-se aparelhos de incorporação, apontam identidades mobilizadas pela energia espiritual do transe de duas ou três e a afirmação de que "é mais um negócio da cabeça dela". Tal afirmativa ainda denota um senso de incompreensão dos processos psicológicos e espirituais pelos quais atravessam aquelas crianças e adolescentes.

A história da iniciação xamânica de Cristiano é detalhada na fala de dona Joana, mãe do rezador, sempre presente em suas idas e "missões" espirituais. Em meio ao movimento de pessoas e ações do rezador, permitiu-nos "um dedo de prosa" sobre a temática em tela:

[...] Desde 18 anos - ele tá com 23 anos -, mas ele carrega isso desde criança, ele fazia "arte" desde criança nos 10 anos, mas eu não acreditava nisso. Ele via era muito, tinha um quadro de São Jorge guerreiro na minha casa e ele ficava horas e horas olhando para aquele quadro assim, ele dizia: "Mãe eu sinto que alguém me puxa pra perto desse quadro." Ele ia pro igarapé, ele chegava chorando, que eles [encantados] tinham levado a sandália dele. Aí ele fazia as coisas, né? E eu batia nele, mas aí ele caiu doente, e ele dizia: "Mãe eu tenho que ajudar alguém, mas eu não sei como." Aí ele caía no quintal e eu chorava em cima dele, aí ele [Cristiano] falou com uma voz diferente [do encantado]: "Não chora que eu não vou matar ele [...] 
na hora certa vão saber o meu nome." Aí por diante ele caía quase todo dia, e ele acordava de noite e enchia de vela dentro de casa até de manhã, passava de dia sem dormir. Eu sofri muito como mãe, o pai já era falecido [...] aí quando foi um dia foi uma voz nele: "Eu sou guia, sou o Caboclo Índio Guerreiro Flechador, o seu filho vai ter que trabalhar, tu vai procurar alguém pra preparar o teu filho." E Cristiano não queria, mas as coisas baixavam nele e jogava ele nos buraco na mata, debaixo dos troncos de árvore que ficava lá prostrado. Aí quando foi um dia, uma irmã da Assembleia de Deus, uma evangélica preparou ele, era a finada Paulina. Ela disse: "Meu filho você é igual a mim, eu vou partir desse mundo e quando eu for você vai sentir, e aí os meus guias vão ir pra ti." Quando a mulher morreu com 95 anos, ele acordou de noite e disse: "Mãe, acorda, se arruma que a dona Paulina morreu”, e daí é que foi mesmo. Eu lhe digo, eu como mãe não gosto, fico me tremendo quando ele vem pra essas peleja. A esposa dele me manda vim pra reparar ele, porque ele faz e diz as coisas e depois não lembra. $\mathrm{O}$ senhor pensa? Depois vou ter que contar tudinho pra ele o que fez aqui, ainda agora ele disse: "Mãe eu tô aqui, mas não tô pisando no chão, pra mim, eu tô é voando." Pra ele, ele tá é flutuando, né? Agora tem uma coisa [... Ele não recebe no corpo mais não, a finada Paulina ensinou pra ele não cair no chão, ela passou o fio pra ele [corda com nós que Cristiano diz ter em casa e usa na cintura], agora ele só conversa, assim como nós estamos falando aqui. Ele reza pra criança, peito aberto, espinhela caída, cura de doença ruim, passa remédio de planta, trabalho de malvadeza, tudo isso ele desfaz. Já veio gente de todas essas bandas, até do Maranhão [...] meu filho nunca cobrou nada de ninguém, lá na vila [Fátima] ele é ajudante de pedreiro e roçador, vive com a mulher e os filhos, mas não explora ninguém, se dão agrado ele recebe só isso. Aqui! Depois disso ele vai passar dois dias na cama tomando caribé e leite quente, porque isso mexe com a cabeça das pessoas, né? (Dona Joana, entrevista realizada em 12/05/2011).

A identidade cultural do rezador-exorcista é tecida no imaginário materno, através do sofrimento que o acompanhou desde a infância; primeiro pelo chamamento xamânico através da imagem de São Jorge, oriunda do catolicismo devocional; segundo, através da violenta ação dos "guias" no corpo e alma do "escolhido" - reino dos encantados; e, terceiro, e não menos importante, o papel da poderosa rezadora evangélica, dona Paulina, que expõe representações de Jesus Cristo como entidade motriz da identidade 
assembleiana (evangélica), tanto no controle das possessões como na relação mediúnica junto ao Caboclo Flechador. ${ }^{22}$

Somamos a esses elementos a relação umbilical entre mãe e filho, identidades plasmadas e mediadas em torno de sentimentos relativos à proteção, ao cuidado, ao medo e à preparação (Tronca, 2004). Dona Joana se intitula o sujeito narrador, voz e percepção de Cristiano, ou ainda, a fala que testifica o seu exercício espiritual na cena do transe.

As características da experiência espiritual de Cristiano sedimentam um processo de construção de uma identidade multifacetada no diálogo com os territórios religiosos das cosmologias amazônicas.

\section{Saídas: "por outros ramais"}

Durante os dias subsequentes, seguindo as visitações de Cristiano no interior das vilas, povoados e ramais de difícil acesso, buscamos contato com as famílias das crianças que passaram pela experiência das possessões e ficamos impressionados ao constatar como a dita sociedade civil e os poderes públicos ignoram as necessidades mais básicas da existência desses agentes sociais: ausência de eletricidade, atendimento médico-hospitalar precário e difícil acesso às escolas são problemas que denunciam as condições de vulnerabilidade a que estão submetidas aquelas populações.

Nas visitas do rezador, os momentos de reza e aconselhamento são intercalados com perguntas de caráter socioeconômico: "vocês já comeram hoje, já ?", “quando chove aqui, vaza muito?”, “ela já sabe ler direitinho, né?”. Tanto Cristiano quanto as pessoas entrevistadas denotam compreensão de que os "problemas" que acometiam crianças e adolescentes estavam associados ao conjunto da vida social, e não apenas à esfera espiritual, demonstrando como populações da floresta explicam, a partir de suas cosmologias, a

22 Além da capacidade de controlar a possessão e interpretar sinais, esses sujeitos podem realizar a saída espiritual do corpo a outros mundos: a viagem xamânica é a capacidade de viajar ao céu ou de descer ao inferno, bem como travar lutas com espíritos, enfrentar outros xamãs, buscar ajuda, proteção e objetos nesses espaços espirituais ( Cavalcante, 2008; Eliade, 1960, p. 113-116; Maués, 1990; Trindade, 2007). Na definição de Cascudo (1972, p. 472), "São Jorge é invocado como defensor das almas contra o demônio, tentações, suspeita de feitiço, rivalizando, dentro de certa medida, com o poderoso São Miguel. Nos Candomblés da Bahia identificam-no com Oxóssi, e Odé, e nas Umbandas do Rio de Janeiro, Recife e Porto Alegre com Ogum." 
indissociabilidade entre campos que foram fatiados por determinada prerrogativa epistemológica.

O exercício do narrar traduz não apenas uma forma de comunicação, mas a principal mediação para se penetrar em camadas das estruturas de sentimento e pertencimento histórico e cultural dessas populações que, esquecidas por poderes públicos, contudo capazes de lutar contra as adversidades da vida, continuam desfazendo mitos e preconceitos, por meio de um modo próprio de dialogar e entender o natural, o humano e o sobrenatural.

Segundo informação dada por moradores locais, entre junho a setembro, o número de casos vem diminuindo consideravelmente nessas comunidades. A imprensa local sustenta a hipótese de que a diminuição desses acontecimentos deve-se a "realização de gincanas, palestras, festinhas estudantis, concurso de redação, programações em datas comemorativas como o dia das mães com o objetivo de trabalhar a mente dos alunos para que os mesmos possam afastar os maus pensamentos" (Correio de Capanema, 2011, p. 3).

A velocidade com que a imprensa local divulga e pretende "solucionar" determinados eventos culturais não deve apressar a reflexão acadêmica e o andamento da pesquisa de campo. As formas de espiritualidade ali emergentes e latentes dialogam com as identidades dos moradores, as quais se refazem nos caminhos e atalhos da história cultural amazônica: os seres da floresta, os mortos e seres malignos assumem, no imaginário local, a função de punir, advertir, amedrontar e instruir os vivos, tornando-se, eles mesmos, força vivificadora e energia condutora da presença humana em solo amazônico (Ginzburg, 2009, p. 77).

As perdas (mortes, traumas, violências, carência econômica, discriminação social e política) são reinventadas e transportadas para suprir lacunas e criar sentidos num tempo em que o direito de viver, dizer não a reedições de epistemicídios, ultrapassar o conformista discurso do multiculturalismo guetizador, tornaram-se ações arriscadas e perigosas. Para além das relações ambíguas entre deuses, forças do mal, homens, mortos e encantados, acima de qualquer pretensão de ter "encontrado" uma verdade, esse exercício de escrita é, acima de qualquer hipótese, o testemunho de que "compartilhar memórias pode significar reavivar sonhos e esperanças", uma forma de "prosseguir sem deixarem-se perder pelo desespero ou mesmo mortes antecipadas" (Antonacci, 2006, p. 21).

Cristiano acredita que o compromisso espiritual com as pessoas da Vila Socorro e demais localidades não constitui uma escolha, e sim um destino, 
uma sina. Por outro lado, o jovem exorcista atribui ao Caboclo Flechador a força que legitimou sua autoridade junto aos encantados e seres incorpóreos.

A forma como transitou nas casas, atravessou quintais e espaço escolar fez do Caboclo Flechador um encantado do ar, que sob a companhia dos anjos paira entre o céu e a terra, como um guardião, um mediador, um tradutor da cosmologia local. Nesses quadros, esse líder da corrente desvela uma identidade desterritorializada, que acaba por borrar generalizações e homogeneidades de compreensões que desejam continuar interpretando a tradicional pajelança cabocla amazônica como territorializada apenas nas águas (Silva, 2011).

Cristiano é um rezador que dificilmente recebe pessoas em casa, sua forma de atuação consiste nos deslocamentos, no ritual do preparo e na expectativa daqueles que recorrem a seus poderes mágico-terapêuticos. Cada investida realizada nas comunidades é uma aventura, uma saga, que, preservada pela força da memória e corporificada pela argamassa de sabedorias orais, o transformam não em mais um estudo de caso, nem tampouco no "maior rezador-exorcista entre Vizeu e Castanhal", de acordo com compreensões de Wilson, mas em um representante de vozes e experiências de tradições afroindígenas que, mesmo vivendo interdições dos poderes constituídos no passado e no presente, renovou-se nas táticas do cotidiano, fazendo do campo das encantarias a última fronteira onde o saber científico, urbanocêntrico, letrado e midiático deixa ver suas fragilidades e incompreensões.

\section{Fontes orais}

Cláudia França, 17 anos, estudante, moradora da Vila Manoel dos Santos - igualmente vinculada ao município de Traquateua. Entrevistada em 03/04/2011.

Joseane de Oliveira, 18 anos, moradora da Vila Fátima, localizada a $12 \mathrm{~km}$ da Vila Socorro, evangélica e descendente de cearenses. Entrevistada em 17/04/2011. Alguns fatos e pessoas foram omitidos a seu pedido.

Glória Maria, 20 anos, moradora da Vila Fátima, católica e descendente de piauienses. Entrevistada em 17/04/2011.

Nazaré Mendonça Alves, 58 anos, moradora da Vila Socorro, católica. Entrevistada em 12/05/2011.

Jair Nunes, 63 anos, colono, residente no ramal que liga Vila Socorro e Tentuga onde vive com esposa e seus cinco filhos, descendente de maranhenses e paraenses. Notamos que em 
quase três horas de informação, o entrevistado revelou que conhecia não apenas as histórias e tradições familiares, mas também tinha fascínio por relatos religiosos, como histórias de santos, aparições, encantos diversos. Entrevistado em 28/04/2011.

Wilson, secretário municipal de Ciência e Tecnologia de Traquateua. Entrevistado em 06/05/2011.

Cristiano, 23 anos, rezador exorcista. Depoimento colhido em 12/05/2011.

Antônia Almeida, 40 anos, moradora local. Depoimento colhido em 12/05/2011.

Joana, viúva e mãe/responsável/acompanhante do rezador exorcista Cristiano em suas incursões e pelejas espirituais nesses povoados amazônicos, é natural da Vila Fátima. O "dedo de prosa" foi realizado na Vila Socorro, em 12/05/2011.

\section{Referências}

ANTONACCI, M. A. Tradições de oralidade, escritura e iconografia na literatura de folhetos: nordeste do Brasil, 1890/1940. Projeto História, n. 22, p. 105-138, jun. 2001.

. O passado presente em memórias de Melgaço. In: PACHECO, A. S. À margem dos "Marajós": cotidiano, memórias e imagens da "Cidade-Floresta" - Melgaço-PA. Belém: Paka-Tatu, 2006. p. 18-20.

BHABHA, H. K. O local da cultura. Tradução de Myriam Ávila, Eliana Lourenço de Lima Reis, Gláucia Renate Gonçalves. Belo Horizonte: Ed. UFMG, 2003.

BURKE, P. A história dos acontecimentos e o renascimento da narrativa. In: BURKE, P. A escrita da história. Tradução de Magda Lopes. São Paulo: Editora da Unesp, 1992. p. 327348.

CASCUDO, L. C. Dicionário do folclore brasileiro: volume 1. Rio de Janeiro: Ediouro, 1954. 1972.

. Dicionário do folclore brasileiro: volume 2. Brasília: Instituto Nacional do Livro,

CAVALCANTE, P. C. De "nascença" ou de "simpatia": iniciação, hierarquia a atribuições dos Mestres na Pajelança Marajoara. Dissertação (Mestrado em Antropologia)-Instituto de Filosofia e Ciências Humanas, Universidade Federal do Pará, Belém, 2008.

CORREIO DE CAPANEMA. Capanema, 22-29 maio 2011.

DELUMEAU, J. História do medo no Ocidente: 1300-1800, uma cidade sitiada. Tradução de Maria Lúcia Machado. São Paulo: Companhia das Letras, 1989. 
ELIADE, M. El chamanismo y las técnicas arcaicas del éxtasis. México: Fondo de Cultura Económica, 1960.

. Imagens e símbolos: ensaios sobre o simbolismo mágico-religioso. Prefácio de Georges Dumézil. Tradução Sônia Cristina Tamer. São Paulo: Martins Fontes, 1991.

FARES, J. A. A matintaperera no imaginário Amazônico. In: MAUÉS, R. H.; VILLACORTA, G. M. (Org.). Pajelanças e religiōes africanas na Amazônia. Belém: Edufpa, 2008. p. 311-326.

FIGUEIREDO, N. Rezadores, pajés \& puçangas. Belém: UFPA, 1979.

FIGUEIREDO, A. de M. A cidade dos encantados: pajelança, feitiçaria e religióes afrobrasileiras na Amazônia. Belém: Edufpa, 2008.

GALVÃO, E. Santos e visagens: um estudo da vida religiosa em Itá, Amazonas. São Paulo: Companhia Editora Nacional, 1975.

GINZBURG, C. O queijo e os vermes: o cotidiano e as idéias de um moleiro perseguido pela Inquisição. Tradução de Maria Amoroso Betânia. São Paulo: Companhia das Letras, 2006.

. Mitos, emblemas e sinais: morfologia e história. 2. ed. São Paulo: Companhia das Letras, 2009.

GOMES, F. dos S. A hidra e os pântanos: mocambos, quilombos e comunidades de fugitivos no Brasil (Séculos XVII-XIX). São Paulo: Ed. UNESP: Polis, 2005.

HALL, S. A identidade cultural na pós-modernidade. Tradução de Tomaz Tadeu da Silva, Guaracira Lopes Louro. Rio de Janeiro: DP\&A, 1999.

. Da diáspora: identidades e mediações culturais. Tradução Adelaine La Guardia Resende. Belo Horizonte: Editora UFMG, 2009.

IBGE. Enciclopédia dos municipios brasileiros: vol. XIV. Rio de Janeiro, 1957.

LE GOFF, J. História e memória. Tradução de Bernardo Leitão. Campinas: Editora da Unicamp, 2003.

LEWIS, I. M. Extase religioso: um estudo antropológico da possessão por espírito e do xamanismo. São Paulo: Perspectiva, 1977.

MAUÉS, R. H. A ilha encantada: medicina e xamanismo. Belém, Universidade Federal do Pará, 1990.

Padres, pajés, santos e festas: catolicismo popular e controle eclesiástico: um estudo antropológico numa área do interior da Amazônia. Belém: Cejup, 1995. 
. A ética na pesquisa antropológica sobre religião. In: LEITÃO, W. M.; MAUÉS, R.

H. (Org.). Nortes antropológicos: trajetos, trajetórias. Belém: EDUFPA, 2008. p. 113-124.

MUCHEMBLED, R. Uma história do diabo: séculos XII-XX. Rio de Janeiro: Bom Texto, 2001.

PACHECO, A. S. À margem dos "Marajós": cotidiano, memórias e imagens da "CidadeFloresta” - Melgaço-PA. Belém: Paka-Tatu, 2006.

. En el corazón de la Amazonía: identidades, saberes e religiosidades no regime das águas marajoara. Tese (Doutoramento em História Social)-Pontifícia Universidade Católica de São Paulo, São Paulo, 2009.

PORTELLI, A. Tentando aprender um pouquinho. Algumas reflexões sobre a ética na História Oral. Projeto História, n. 15, p. 13-33, abr. 1997.

PRANDI, R. Encantaria brasileira: o livro dos mestres, caboclos e encantados. Rio de Janeiro: Pallas, 2004.

SILVA, J. da S. e. "No ar, na água e na terra": uma cartografia das identidades nas encantarias da "Amazônia Bragantina" (Capanema-PA). Dissertação (Mestrado em Comunicação, Linguagens e Cultura)-Universidade da Amazônia, Belém, 2011.

SOUZA, L. de M. Inferno atlântico: demonologia e colonização: séculos XVI-XVIII. São Paulo: Companhia das Letras, 1993.

THOMPSON, E. P. A miséria da teoria ou um planetário de erros (uma crítica ao pensamento de Althusser). Trad. de W. Dutra. Rio de Janeiro: Zahar, 1981.

THOMSON, A. Recompondo a memória: questões sobre a relação entre a História Oral e as memórias. Projeto História, n. 15, p. 51-71, abr. 1997.

TRINDADE, R. "Aqui, a cura é de verdade": reflexões em torno da cura xamânica em São Caetano de Odivelas-PA. Dissertação (Mestrado em Antropologia)-Instituto de Filosofia e Ciências Humanas, Universidade Federal do Pará, Belém, 2007.

TRONCA, I. Foucault, a doença e a linguagem delirante da memória In: BRESCIANI, S.; NAXARA, M. (Org.)Memória e (re)sentimento: indagações sobre uma questão sensível. Campinas. Editora da Unicamp, 2004. p. 129-148.

VIVEIROS DE CASTRO, E. Os pronomes cosmológicos e o perspectivismo ameríndio. Mana, v. 2, n. 2, p. 115-144, 1996.

ZUMTHOR, P. Performance, recep̧̧ão, leitura. Tradução de Jerusa Pires Ferreira e Suely Fenerich. São Paulo: EDUC, 2000. 
WILLIAMS, R. Marxismo e literatura. Rio de Janeiro. Zahar, 1979.

. O campo e a cidade: na história e na literatura. Tradução Paulo Henriques Britto. São Paulo: Companhia das Letras, 1989.

Resumo: Neste ensaio, seguindo rastros da metodologia da história oral, através de entrevistas com diferentes moradores, e mapeando discursos midiáticos, discutiremos sentidos de possessões indígenas e africanas em populações que habitam a Amazônia Bragantina. A base teórica parte dos estudos culturais e pós-coloniais, alcançando a antropologia das religiôes para acompanhar possessôes coletivas em crianças e adolescentes do sexo feminino na Vila Socorro ( $\mathrm{km}$ 14), no município de Traquateua (PA). Completamos o enredo do texto, apresentando o jovem xamã Cristiano que, ao operar com poderes do Caboclo Flechador, frente a entidades incorpóreas, mortos-vivos e demônios, desvela sentidos e memórias que povoam corpos e dons espirituais emergentes no seio das populações locais. A interpretação aponta que a avaliação apressada dos acontecimentos como "fenômenos sobrenaturais" pelos meios de comunicação silencia tradições de culturas afroindígenas neste portal da Amazônia brasileira.

Palavras-chave: oralidade, possessões, cultura afroindígena, Amazônia Bragantina.

\section{Oralities in times of possessions afroindígenas}

Abstract: In this essay, following the traces of Oral History Methodology, through interviews with residents, and mapping different media discourses, we discuss the meanings of indigenous and African possessions among populations that inhabit the Bragantine Amazon. The theoretical approach starts from the Cultural and Post-Colonial Studies, reaching the Anthropology of Religions to accompany collective possessions in children and female adolescents at Socorro village (Km 14), in the municipality of Traquateua. We complete the plot of the text introducing the young shaman Cristiano, who, to operate with powers from Caboclo Flechador, facing intangible entities, undead and demons, unveils senses and memories that inhabit bodies and spiritual gifts emerging within local populations. The interpretation indicates that a hasty assessment of events, such as "supernatural phenomena" by the media, silents traditions of afro indigenous cultures at this portal of the Brazilian Amazon area.

Keywords: orality, possessions, afro indigenous cultures, Bragantine Amazon.

Recebido em 10/09/2012

Aprovado em 24/11/2012 